\title{
Freedom of Religion and Freedom from Religion
}

\author{
BARONESS HALE OF RICHMOND ${ }^{1}$ \\ Deputy President of the Supreme Court
}

The right to freedom of religion, enshrined in the European Convention on Human Rights has been frequently tested, both in UK courts and in the European Court of Human Rights, where successive decisions over a number of years led to the establishment of several well-known principles. However, in recent years religious extremism has brought into focus a tension between the right of freedom of religious expression and the well-being of individuals (not least children) and society. The Strasbourg court requires neutrality on the part of the state and its courts. However, unlike the European Court of Human Rights, the domestic courts have had to face situations where religious observance can be seen to be causing serious harm and where interference in religious freedom and family life has been shown to be justified.

Keywords: freedom of religion, religious extremism, radicalisation

Talking about freedom of religion used to be relatively straightforward. Article 9 of the European Convention on Human Rights, given legal force in the United Kingdom by the Human Rights Act 1998, protects both freedom of religion and belief and the freedom to manifest those beliefs, in worship, teaching, practice and observance. Article 10 protects freedom of expression and Article 11 protects freedom of assembly and association, both of which are important aspects of exercising religious freedom. Also significant in protecting religious freedom is Article 8, which gives positive protection to the right to respect for private and family life and prohibits the state from interfering. Thus families are supposed to be free to bring their children up in their own religious beliefs, a right reinforced by Article 2 of the First Protocol in relation to the right to education.

Article 14 of the Convention protects against discrimination in the exercise of any of the fundamental rights protected by the Convention on account of religion or belief. Finally, the Equality Act 2010 protects against discrimination by public or private suppliers of employment, education, accommodation, goods and services on account of their religion or belief (or lack of it). ${ }^{2}$ 


\section{THE DEVELOPMENT OF PRINCIPLES}

The courts, both here and in Strasbourg, have developed some well-known principles in applying those rights. First, although these laws protect both freedom of religion and freedom of belief (or the lack of it), something which qualifies as a religion is likely to qualify for protection automatically, whereas a non-religious belief system may have to reach such a level of seriousness and coherence as to merit the law's protection. ${ }^{3}$ Nor will it be so obvious what is a 'manifestation' of such a belief. Apparently, wearing a cross is a manifestation of Christian beliefs, whereas distributing leaflets to troops in an attempt to dissuade them from serving in Ireland is not a manifestation of pacifist beliefs. ${ }^{4}$

Second, that freedom is given to all religions, no matter what their source or respectability. No special protection is given to Christianity or indeed to any of the major world religions. Scientology qualifies as a religion, because it falls within Lord Toulson's 'working definition' adopted by the United Kingdom Supreme Court:

a spiritual or non-secular belief system, held by a group of adherents, which claims to explain mankind's place in the universe and relationship with the infinite and to teach its adherents how they are to live their lives in conformity with the spiritual understanding associated with that belief system. By spiritual or non-secular I mean a belief system which goes beyond that which can be perceived by the senses or ascertained by the application of science. ${ }^{5}$

The Strasbourg court regards such tolerant pluralism as essential to democracy but it clearly also poses a challenge to democracy when some religions, perhaps many, do not share those same values.

Third, the role of the state is to be a 'neutral and impartial organiser of the exercise of various religions, faiths and beliefs'. Its 'duty of neutrality and impartiality is incompatible with any power on the State's part to assess the legitimacy of religious beliefs or the way those beliefs are expressed'. ${ }^{6}$ It is not for us to argue, for example, with a Muslim schoolgirl's beliefs about the dress code which her religion obliges her to follow, provided those beliefs are genuinely held.?

Fourth, however, religious freedom is a qualified right. There is an absolute right to believe whatever one chooses to believe. But the freedom to manifest

$5 \quad R$ (Hodkin) $v$ Registrar of Births, Deaths and Marriages [2013] UKSC 77, [2014] AC 610.

6 SAS v France (2015) 60 EHRR 244 at para 127.

$7 \quad R(S) v$ Governors of Denbigh High School [2006] UKHL 15, [2007] 1 AC 100. 
those beliefs, or to express them, or to assemble and associate with others in order to do so, or to bring up one's children to follow them, may be subject to limitations. These always have to be 'prescribed by law' and 'necessary in a democratic society' for a variety of legitimate purposes. Purposes common to all four of the relevant Convention rights are the interests of public safety, the protection of health or morals, and the protection of the rights and freedoms of others. The freedoms of speech and of association and the right to respect for family life can also be limited in the interests of national security or public safety or for the prevention of disorder or crime, whereas freedom of religion can only be limited for the purpose of public order. I do not know why this is and it might be significant: should it be possible to limit freedom of religion in the interests of national security?

Fifth, as a very broad generalisation, therefore, one is not allowed to claim the freedom to do harm to other people because of one's religious beliefs. A parent cannot deny her child the medical treatment he needs to protect his life or health because her religion prohibits such treatment. If the child suffers harm as a result, the parent can be prosecuted. But the law will usually step in first to authorise the treatment before the child is harmed. A person cannot stir up religious hatred when exercising his or her right to freedom of speech. Thankfully, however, there is no crime of simply injuring religious feelings (as the Law Commission came close to recommending in $1985^{\circ}$ ).

Sixth, no-one is allowed to use religion as an excuse for breaking the general laws which are there to protect the common good, unless the law itself makes an exception. Thus, for example, Christian hotelkeepers were not allowed to discriminate against same-sex couples in the rooms they would let them share. ${ }^{9}$ But Sikh motorcyclists have long been granted a statutory exemption allowing them to wear turbans instead of crash helmets. ${ }^{10}$ The difference in principle, of course, is that the only harm done is to the believer himself, if he is injured in an accident, whereas the hotelkeeper harms the same-sex couple in a particularly demeaning way."

Seventh, religious discrimination will rarely be direct - 'no Jews here', for example. Sometimes it will be what is usually referred to as Thlimmenos discrimination: that is, treating situations as if they are alike, when in fact they are not alike and an exception ought to be made. An exception to the general rule that chartered accountants must not have felony convictions should have been made

8 Report on Offences against Religion and Public Worship, 1985, Law Com No 145, recommended the abolition of the crimes of blasphemy and blasphemous libel, without replacement, by a majority of three to two.

9 Bull v Hall [2013] UKSC 73, [2013] 1 WLR 3741.

10 Road Traffic Act 1988, s 16(2).

11 I make no comment on the case concerning Christian bakers who objected to the message a gay customer wanted iced on a cake, which raises some different issues. 
for a Jehovah's Witness convicted for refusing to do compulsory military service because of his religious beliefs. ${ }^{12}$ At other times it will be indirect discrimination - applying a provision, criterion or practice which applies to everyone, so is neutral on its face, but puts adherents of one religion at a particular disadvantage in comparison with others, and the complainant suffers that disadvantage. In both situations, the discriminator is expected to make reasonable adjustments to mitigate the disadvantage. British Airways should have let Mrs Eweida wear her cross; their reasons for not doing so were not good enough. ${ }^{13}$ But should the law courts let female parties or witnesses cover their faces, and if so when?

\section{THE PROBLEM OF EXTREMISM}

So far, so reasonably straightforward. The principles are clear, even if they are not always easy to apply in practice. The law allows people to hold and practise their religious beliefs, as long as they do not do harm to others. Providers of employment, goods and services are expected to adapt their rules and practices so as to accommodate religious practices, so long as it is reasonable to expect them to do so. But Islamist (and far right) extremism is bringing with it some particular problems in reconciling the various interests at stake.

The Government's 'Prevent' strategy has recently been placed on a statutory footing, in the Counter-Terrorism and Security Act 2015. A wide range of public authorities and private providers of public services are now required to 'have due regard to the need to prevent people from being drawn into terrorism'. ${ }^{14}$ Terrorism is extremely widely defined in the Terrorism Act 2000 . The aim of the Prevent strategy is to reduce the threat from terrorism by stopping people becoming terrorists or supporting terrorism.

The thesis is that extremist beliefs, even if expressed in non-violent ways, are a breeding ground for terrorism. The Government's Prevent Duty Guidance explains that the strategy is to deal with all forms of terrorism and non-violent extremism 'which can create an atmosphere conducive to terrorism and can popularise views which terrorists then exploit'. ${ }^{15}$ These need to be challenged. The Government defines extremism as 'vocal or active opposition to fundamental British values, including democracy, the rule of law, individual liberty and mutual respect and tolerance of different faiths and beliefs' (as well as calling for the death of members of the armed forces). The most significant threats

12 Thlimmenos v Greece (2001) 31 EHRR 15.

13 Eweida $v$ United Kingdom (2013) 57 EHRR 213.

14 Counter-Terrorism and Security Act 2015, s 26(1).

15 HM Government, Revised Prevent Duty Guidance for England and Wales: guidance for specified authorities in England and Wales on the duty in the Counter-Terrorism and Security Act 2015 to have due regard to the need to prevent people from being drawn into terrorism, revised 16 July 2015, available at <https:// www.gov.uk/government/uploads/system/uploads/attachment_data/file/445977/3799_Revised_ Prevent_Duty_Guidance_England_Wales_V2-Interactive.pdf $>$, accessed 10 October 2016. 
come from terrorist organisations in Syria and Iraq and groups associated with al-Qaida. As the Guidance explains:

Islamist extremists regard Western intervention in Muslim-majority countries as a 'war with Islam', creating a narrative of 'them and us'. Their ideology includes the uncompromising belief that people cannot be both Muslim and British, and that Muslims living here should not participate in our democracy. Islamic extremists specifically attack the principles of civic participation and social cohesion. ${ }^{16}$

So the authorities and providers are expected to be on the lookout for it, to identify people at risk, in particular children and young people, and to take steps to protect them. Social services should have 'clear and robust safeguarding policies to identify children at risk' and action plans to protect them. Schools and even early years providers should do the same. When they have identified children at risk, they will need to decide on the most appropriate referral, to the 'Channel' programme or to children's social care. 'Preventing someone from being drawn into terrorism is substantially comparable to safeguarding in other areas, including child abuse or domestic violence. ${ }^{17}$ The clear message is that compulsory action may have to be taken to protect these children from the harm of being radicalised.

This message had already been heard by the childcare authorities, who have been bringing cases before the Family Division of the High Court in an attempt to protect children from radicalisation. There have been so many that the President of the Family Division has given guidance about how they should be conducted. ${ }^{18}$ There was a rush of cases reported in 2015 which aimed to prevent young people either going on their own to Syria or other so-called Islamic State-controlled areas, or being taken there by their families. The case of $Y$, for example, concerned a 16-year-old boy whose uncle was detained in Guantanamo Bay and whose family were committed to jihad. Two of his brothers had already died in Syria and another had been injured. He was about to travel to Dubai. The local authority made him a ward of court to prevent his boarding the flight. ${ }^{19}$ The case of $Z$ concerned a 16 -year-old girl of Somali heritage whom the Counter-Terrorism Intelligence Unit thought had been radicalised and intended to travel to Syria. Again, she was made a ward of court to prevent her travelling. ${ }^{20}$ In London Borough of Tower Hamlets $v$, two local

16 Ibid, p 3.

17 Ibid, pp 7, 13.

18 President's Guidance: radicalisation cases in the family courts [2015] Fam Law 1527 (Dec).

$19 \operatorname{Re}$ Y (Wardship) (No 1) [2015] EWHC 2098 (Fam), [2016] 2 FLR 225; Re Y (Wardship) (No 2) [2015] EWHC 2099, [2016] 2 FLR 229. 
authorities from different parts of the country made a number of children wards of court for fear of them travelling to areas under ISIS control. ${ }^{21}$

In other cases, the whole family has been prevented from travelling or brought back after starting out. The case of $M$ hit the headlines in May 2015 because the father, mother and four children were stopped at the border between Turkey and Syria and eventually brought back to the UK. ${ }^{22}$ The children had been made wards of court but this was not made public at first for fear that the family might not return. The President of the Court promised a further judgment about what happened next (but as far as I know this has not yet been published).

The case of $X$ and $Y$ concerned two whole families. ${ }^{23}$ The $X$ family consisted of the mother, the maternal grandmother, an uncle and four children, who were detained as they were about to fly to Turkey. The Y family - two mothers, one father and two children each - did fly to Turkey but were returned. Initially in these cases there were Children Act proceedings and the children were placed with foster parents. But the parents proposed that they be returned home as wards of court with a range of orders to prevent their being taken abroad again - surrendering passports, an all-ports alert, injunctions restraining the parents from taking them abroad and requiring them to live with the children at a specified address, and provisions for monitoring, including unannounced visits by social workers and regular reporting to the police, coupled with electronic tagging of the adults. The tagging was a novelty to which the Ministry of Justice (which would have to foot the bill) initially objected, but it was eventually ordered so that the children could go home.

In all of these cases, therefore, the action taken stopped short of permanently removing the children from home in order to protect them from going or being taken to Syria. But in London Borough of Tower Hamlets $v$, the court concluded that removal from home was the only way to protect a 16 -year-old girl whose flight had been intercepted moments before take-off. ${ }^{24}$ Her parents promised to co-operate and her passport was deposited with their solicitors rather than, as more usually, with the court. But a few months later a police search of the family home found electronic devices with all sorts of radical material on them. The judge commented that the impact of the list of material was 'powerful and alarming ... it is not merely theoretically or gratuitously shocking, it involves information of a practical nature designed to support and to perpetuate terrorist attacks'. ${ }^{25}$ The girl and her parents were arrested. The local authority 
sought the removal from home not only of the girl but also of her brothers. The judge ordered further assessment of the boys: the radicalised material was not found on their devices; they had a much wider integration into society generally, through their sporting and other interests; one of the boys had sounded the alarm about his sister's flight; and two of them were about to start sixth-form college (it may not be insignificant that the children had all been - very successfully - home-educated). So he was not yet in a position to decide whether to remove them from home. But he concluded that the girl was at such risk of harm, and her parents had been so devious and dishonest, that she could only be protected by removal from home into institutional care.

In a way, these cases may not seem difficult. Travel to ISIS-controlled areas obviously involves a risk of really serious harm to these children. The boys will be at risk of death or injury in the fighting, as well as of grave psychological harm from the brutalisation to which they may be subject. The girls will also be at risk of rape and other sexual abuse and forced marriage. We should do all we can to protect them from these risks, while trying hard to avoid further alienation from British society. Hence the care the courts have taken to interfere to the least extent compatible with protection, making the child a ward of court and impounding passports, rather than taking the child away from the family.

More difficult in principle, however, is removing a child from home because of the harmful effects of radicalisation itself. In another, earlier, case of $M, \mathrm{Mr}$ Justice Holman complained that:

'radicalising' is a vague and non-specific word which different people may use to mean different things ... If and insofar as what is meant in this case by 'radicalising' means no more than that a set of Muslim beliefs and practices is being strongly instilled in these children, that cannot be regarded as in any way objectionable or inappropriate. On the other hand, if by 'radicalising' is meant ... 'negatively influencing [a child] with radical fundamentalist thought, which is associated with terrorism' then clearly that is a very different matter altogether. If any child is being indoctrinated or infected with thoughts involving the possibility of 'terrorism' or, indeed, hatred for their native country, which is England, or another religion, such as Christianity, which is the religion of their grandparents and now, again, their mother, then that is potentially very abusive indeed and of the utmost gravity. ${ }^{26}$

That was a case which had started as a dispute between the mother and the father over their seven children. The father was a born Muslim. The mother 
came from a Presbyterian family but had converted to Islam before meeting and marrying the father. They had become estranged after the father had taken the whole family to Libya, perhaps intending to remain there. The mother had succeeded in getting the children back to England and they were now living with her. The dispute was about whether the father's contact should be supervised. The local authority were initially supportive of the mother's care, but suddenly announced their intention to bring care proceedings, because of the mother's complaints that the father was radicalising the children.

In the more recent case of London Borough of Tower Hamlets $v B$, mentioned earlier, the judge had

no hesitation in concluding that B has been subject to serious emotional harm, and, at the very least, continues to be at risk of such in her parents' care. I can see no way in which her psychological, emotional and intellectual integrity can be protected by her remaining in this household. The farrago of sophisticated dishonesty displayed by her parents makes such a placement entirely unsustainable. ${ }^{27}$

Interestingly, he drew a comparison with sexual abuse:

If it were a sexual risk that were here being contemplated, I do not believe that any professional would advocate such a placement for a moment. The violation contemplated here is not to the body but it is to the mind. It is every bit as insidious, and I do not say that lightly. It involves harm of similar magnitude and complexion.

What the girl needed was 'to be provided with an opportunity in which she can, in a peaceful and safe situation, be afforded the chance for her strong and lively mind to reassert its own independence'. ${ }^{28}$ Finding the right place for her to do that would not be easy.

This is a clear indication that the family court is prepared to regard the inculcation of extremist beliefs as producing the sort of significant harm which justifies removing a child from home. It was a shift from the harmful consequences of such beliefs - in travel to Syria - to the harmful psychological effects of even holding such beliefs. This is an important development, and one to be treated with great caution.

Boris Johnson has apparently called for the law to treat radicalisation as a form of child abuse. ${ }^{29}$ Social workers may feel themselves under pressure to 
bring care proceedings because of the religious or political views of the child's parents. Indeed, because of the Prevent Strategy and the 2015 Act, they may believe that it is their duty to do so. It is easy to justify such intervention in the cause of preventing terrorism. But where might it lead?

It is not difficult to think of other religious beliefs which might be considered harmful to a child's physical or psychological development. We can deal with the parents' religiously motivated resistance to necessary medical treatment by providing an alternative authorisation for it, usually through what is known as a 'specific issue' order under the Children Act 1989. But we agonise about whether it is right to deal with an adolescent child's own religiously motivated resistance to necessary medical treatment. That is the main dilemma facing the family court judge in Ian McEwan's splendid novel The Children Act. So far our law has taken the view that, while the child is a child, however competent he is to make his own decisions, the courts are entitled to make the decision for him in his own best interests, at least where life-saving treatment is involved. ${ }^{30}$ But what about harm to psychological development? This is not so easily dealt with. As in the case of $B$, removal from home may be the only way to counter the insidious influence of the views of parents and even of other children. So are we not driven to asking ourselves what sort of religious beliefs amount to psychological harm and what do not? This is a decidedly scary thought.

If we go back to first principles, families are entitled to bring up their children as they see fit:

In a totalitarian society, uniformity and conformity are valued. Hence the totalitarian state tries to separate the child from her family and mould her to its own design. Families in all their subversive variety are the breeding ground of diversity and individuality. In a free and democratic society we value diversity and individuality. Hence the family is given special protection in all the modern human rights instruments including the European Convention for the Protection of Human Rights and Fundamental Freedoms (art 8), the International Covenant on Civil and Political Rights (art 23) and throughout the United Nations Convention on the Rights of the Child. As McReynolds J famously said in Pierce $v$ Society of Sisters, ${ }^{31}$ 'The child is not the mere creature of the State'. ${ }^{32}$

That is why the Review of Child Care Law in 1985 , which led to the Children Act 1989 , recommended that compulsory state intervention in family life was only justified where the child had suffered or was at risk of suffering significant 
harm. In the 1989 Act, harm means ill-treatment or the impairment of health or development. Development means physical, intellectual, emotional, social or behavioural development. ${ }^{33}$

What we did not adequately address then was the extent to which notions of psychological harm are culturally and religiously determined. Members of one faith may believe that women are subordinate creatures with very limited power and right to determine their own destiny. It would be harmful to them to come to believe anything else. Members of another faith may believe that women are not subordinate creatures and are entitled to equal treatment in the outside world, but still believe that they are not entitled to play an equal part with men in the priestly role. Members of still another faith may believe that women are as qualified as men to minister to the faith and to the congregation. So are any of these harmful to the psychological development of the young people brought up in those views?

We have something like this issue before us in the UK Supreme Court at the moment. ${ }^{34}$ The Scottish Parliament has ruled that every child living in Scotland should have a 'named person' to promote and support their 'well-being'. If all that is envisaged is a 'one-stop shop' for children and their parents to be helped to get access to the services the child needs, that is one thing. If what is envisaged is that parents should conform to a particular state-determined model of bringing up children, that is a very different thing. It is not a coincidence that the NGO playing the lead role in challenging this legislation is the Christian Institute. It can, of course, be argued that the legislation does not raise the threshold for compulsory intervention in the family, which remains harm-based, but their worry is that it sets out to promote the state's view of the well-being of children rather than leaving it to the children and families themselves to find their own ways to wellbeing. The aim is early intervention to nip possible deficits in well-being in the bud, which is also the aim of the Prevent strategy.

\section{CONCLUSION}

I find this a really difficult issue. I believe in the diversity and subversiveness of the family as an essential component in democracy. I believe in religious freedom. But at the same time it is really hard to treat all religions equally if they are not prepared to do the same in return. The neutrality required by the European Court of Human Rights is all well and good. But they have not yet been confronted with cases where it appears that religious beliefs are doing real harm, not only to their adherents but also to others.

34 The Christian Institute and others $v$ Lord Advocate [2016] UKSC51, 2016 SLT 805. Judgment was given on 28 July 2016. 
What does seem clear, however, is that the notion is developing that inculcating certain religious beliefs can be harmful enough to justify state intervention in family life. It is hard to reconcile that development with the neutrality that the European Court of Human Rights expects of us. It is also hard to reconcile it with the refusal to interrogate the justification for the belief which the European Court of Human Rights also expects of us. I foresee some lively debates to come. 